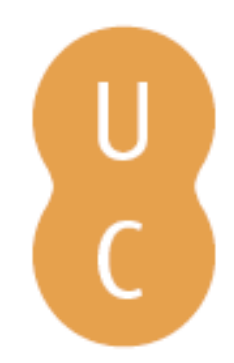

\title{
nommalina
}

\section{Media and the quality of democracy: the different impacts of the media on regime support in Brazil}

\author{
Autor(es): $\quad$ Mesquita, Nuno Coimbra \\ Publicado por: Imprensa da Universidade de Coimbra \\ URL \\ persistente: URI:http://hdl.handle.net/10316.2/35142 \\ DOI: $\quad$ DOI:http://dx.doi.org/10.14195/978-989-26-0917-1_1 \\ Accessed : $\quad$ 26-Apr-2023 16:11:05
}

A navegação consulta e descarregamento dos títulos inseridos nas Bibliotecas Digitais UC Digitalis, UC Pombalina e UC Impactum, pressupõem a aceitação plena e sem reservas dos Termos e Condições de Uso destas Bibliotecas Digitais, disponíveis em https://digitalis.uc.pt/pt-pt/termos.

Conforme exposto nos referidos Termos e Condições de Uso, o descarregamento de títulos de acesso restrito requer uma licença válida de autorização devendo o utilizador aceder ao(s) documento(s) a partir de um endereço de IP da instituição detentora da supramencionada licença.

Ao utilizador é apenas permitido o descarregamento para uso pessoal, pelo que o emprego do(s) título(s) descarregado(s) para outro fim, designadamente comercial, carece de autorização do respetivo autor ou editor da obra.

Na medida em que todas as obras da UC Digitalis se encontram protegidas pelo Código do Direito de Autor e Direitos Conexos e demais legislação aplicável, toda a cópia, parcial ou total, deste documento, nos casos em que é legalmente admitida, deverá conter ou fazer-se acompanhar por este aviso.

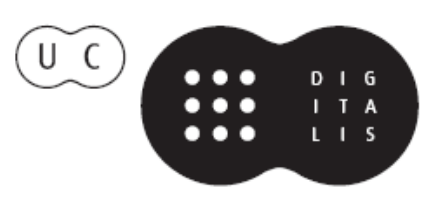




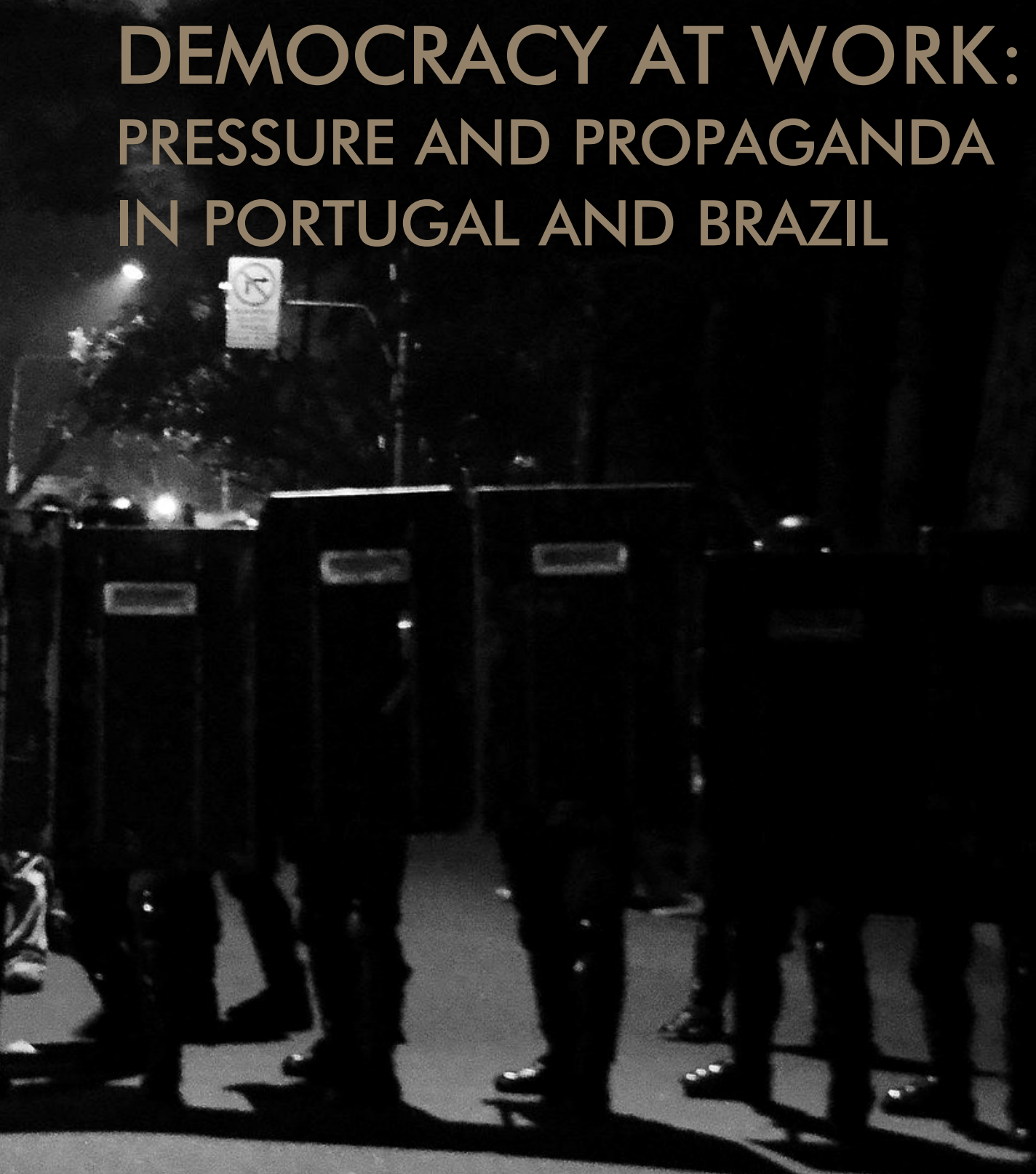

IMPRENSA DA UNIVERSIDADE DE COIMBRA COIMBRA UNIVERSITY PRESS
RITA FIGUEIRAS

PAULA ESPÍRITO SANTO.

ISABEL FERIN CUNHA 
CH A P T E R 1

\title{
MEDIA AND THE QUALITY OF DEMOCRACY: THE DIFFERENT IMPACTS OF THE MEDIA ON REGIME SUPPORT IN BRAZIL
}

\author{
Nuno Coimbra Mesquita
}

\section{Introduction}

With Brazilian democracy having already surpassed the milestone of its 20 years - considering its new democratic constitution and the first direct presidential elections after military rule - support for the regime reaches its highest rates. In 1989 only 44\% of Brazilians believed democracy as the best form of government. In 2006 that number reached 71\% (Moisés 2008). Political support is fundamental to the understanding of the quality of democracy. After democracy spread to most countries of the world, scholarly attention has turned more to this aspect than to the analysis of the transitions themselves (Diamond and Morlino 2004).

Some of the perspectives concerning media impact on democracy point to a growing cynicism of the press in dealing with public issues, leading to the belittlement of politics and politicians in general (Patterson 1998,

\footnotetext{
1 This chapter is a result of a post-doctoral research financed by the Fundação de Amparo à Pesquisa do Estado de São Paulo (Fapesp). An earlier version of this text was published as "Mídia e Apoio Político à Democracia no Brasil" in Moisés, J.A.; Meneguello, R. (orgs) "A Desconfiança Política e os seus Impactos na Qualidade da Democracia". São Paulo, Edusp, 2013. This text was reviewed and updated.
} 
Cappella and Jamieson 1997). On the other hand, studies based on surveys indicate that news media exposure is associated with more democratic attitudes and trust in the regime (Norris 2000, Newton 1999). Regardless of the perspective adopted on the subject, the information about institutions in the media is an element available to citizens to form their opinions, beyond the concrete experiences they may have. Therefore, what can be said about the role played by the media in the quality of democracy? More specifically, how is public support for the democratic regime affected by media exposure?

We argue that there are two sets of multidimensionality of the phenomenon. On the one hand, public support for democracy comprises different dimensions. People can be deferential to democracy per se, but distrust their institutions; adhere to the political community, but be dissatisfied with the functioning of democracy as it presents itself, or even evaluate critically its institutions. On the other hand, media also presents itself as multidimensional. The information contained - and audience reach - are not the same in a quality newspaper or in a newscast. Television broadcasts entertainment programs with different characteristics, each with the potential to affect differently the understanding that individuals have about the affairs of the State.

The purpose of this paper is to analyze the interrelationships between these different dimensions. The main objective of this study is to evaluate how different mass media are relevant for citizens' orientations toward the political system. Is this exposure beneficial or detrimental to a democratic political culture? We argue that the media present a plural role in democratic attitudes, depending both on the specific media and on the dimension of political support taken into account. This paper focuses its analysis on five media variables: exposure to news on newspapers, TV, radio and Internet, and total TV exposure. We want to know if these media variables are associated positively or negatively with political support. The chosen methodological approach to the problem was statistical analyses of national public opinion surveys. Using regression models for prediction purposes, it is possible to evaluate what set of variables (media exposure) affect dependent variables (citizens' attitudes toward the political system). We use data from the survey 'Citizens' Distrust in Democratic Institutions' (2006), and from the 'Latin American Public Opinion Project' (2008). 
The paper initially discusses the issue of political support as an aspect of the quality of the regime, reviewing the literature on the debate about the effects of mass media on the democratic process. Next, from the singularities of the Brazilian case, we present the hypotheses that orient the research. Then, we show the results of Brazilians' main media source (TV), followed by secondary news sources (newspapers, radio and the Internet). The final considerations try to reflect on the role played by the media in the quality of democracy.

\section{Media and the Quality of Democracy}

Attitudes of democratic support are essential for the quality of the regime. Studies on democratic quality intensified after the Third Wave of democratization, and also after signs of growing discontent with actual regime performance of older democracies. Therefore, a greater academic effort was made to investigate how regimes really work, instead of questions of $w h y$ the transitions occurred. Diamond and Morlino (2004) defined the rule of law, competition, participation, accountability, freedom, equality and responsiveness as crucial dimensions for democratic quality. These authors suggest that the quality of the regime varies as much as these dimensions interact between themselves.

We turn our attention here to the responsiveness dimension. Since it has to do with consonance between policies adopted by elected officials and aspirations of electors-citizens, it is related to the level of satisfaction with regime performance and the legitimacy that participants of the polity ascribe to it. Hence, under this perspective, the study of political support is crucial to the understanding of the quality of democracy. The question of political support comprehends different dimensions. Easton's (1965) original idea of diffuse support - i.e. attitudes toward the system as a whole - and specific support - i.e. concerning citizens' satisfaction with government and political leadership performances - has been further elaborated in some theoretical approaches.

Some authors have identified five levels of this type of attitude: support for the political community (related to bonds between citizens and 
the nation-state, usually measured by feelings of national pride); for the democratic regime per se (related to democratic adherence as an ideal, connected with values such as freedom, rule of law, participation and tolerance); for the actual performance of the democratic system, measured by satisfaction with the regime; for democratic institutions (measured by levels of trust in them) and for political leaders (related to the evaluation of politicians and political leaders) (Norris 1999, Moisés and Carneiro 2010).

Associated with the question of adherence to regime principles is the intermediary function of political parties. Understood as a requirement for the democratic ideal, their valorization constitutes one of the essential elements of this adherence. This valorization can be seen as composed both by normative and pragmatic orientations. The former refers to the axiological role that political parties should fulfill in democracy. Differently, the latter is the perception of the real performance of parties as well as proximity between citizens and them.

Political support, taking into account these different dimensions, has varied in consolidated democracies. While support for the community and democratic principles remained high, trust in politicians and evaluation of the performance of the democratic system have fallen in many consolidated as well as young democracies (Norris 1999, Dalton 1999). In Brazil, public support for the regime presents a paradoxical picture. While adherence to democracy as an ideal reaches $2 / 3$ of citizens - having increased since 1989, when it reached only about half of them - trust in institutions, evaluation of the main actors and satisfaction with the democratic system have inverse levels (Moisés 2007).

Different theoretical perspectives try to explain what determines these attitudes toward the political system. Studies of political culture, for example, emphasize aspects like political values or normative orientations of citizens. In this sense, this variety of shared attitudes and beliefs - like political interest, tolerance, national pride, political efficacy, and institutional and interpersonal trust - are supposed to influence the conceptions that inform people's involvement with public life. Although this theory postulates that these orientations are long lasting, changes are expected to occur. That is the case of processes of economic and social moderniza- 
tion, for example (Inglehart and Welzel 2005). Therefore, aspects such as political orientations and values are seen as influencing citizens' choice to accept the democratic regime as their preferable alternative (Almond and Verba 1963, Inglehart 2002).

Institutional theories of democracy, nevertheless, not considering these factors, believe in the actual performance of governments and its institutions as elements that explain phenomena like trust or regime support (Coleman 1990, North 1990). These perspectives should not necessarily mean rival hypotheses. Political culture, as well as institutional evaluation, can affect in different ways individuals' experiences and influence their political orientations (Moisés 2010).

The importance of the media to explain adherence, likewise, should not be seen as a challenging hypothesis. Given the importance of the media in contemporary societies, in their role of informing citizens over public issues, we argue that they influence public perception of institutions and democracy. From this point of view, the influence of the media should not be seen dissociated from the culturalist or institutionalist approaches. The reason is that, on the one hand, they are responsible for disseminating practical information about institutions. This information, together with actual experience that citizens have with them, provides a base for individuals to form their attitudes regarding the system. On the other hand, the media are also responsible for transmitting values, which could influence more normative perceptions that citizens have of their political system. The complex relationship between politics and communicative processes has been studied under a convergence of different disciplines and ascribed the general label of political communication. Among diverse research interests in this field, different approaches try to estimate the impact of the media on citizens' values and cognition. While media malaise theories point to an adverse effect caused by an emphasis on negative aspects of political life portrayed by the media, political mobilization approach stresses that news exposure has the capacity to better inform the public, leading to a positive impact on the political process.

During the 1990's, media criticisms became common, reflecting a climate of '(...) angst about the vitality of democracy at a time of widespread 
cynicism about political leaders and government institutions (...)' (Norris 2000: 6). Patterson (1998) states that political parties and representative institutions have weakened in the post-industrial era. The media are increasingly expected to compensate for the defects of political institutions. They are not required just to inform citizens about current affairs or to watch for wrongdoings. It is also expected that they take a preeminent position in setting the public agenda, organizing public discussions and instructing citizens on relevant values in policy problems and issues. The media, however, are not suited for organizing public opinion and debate because of the restricted amount of time they have. Patterson (2000) also states that American journalism depicts politics as a game - in which politicians, as individuals, struggle for power - instead of as an issue. Furthermore, there is American media's adversarial stance, with a greater proportion of negative in relation to positive news. The consequence would be the disenchantment of citizens with their leaders and political institutions.

Television is also blamed for civic disengagement in contemporary society, as is the case of the disappearance of 'social capital' (Putnam 1995). Interpersonal trust - a central variable in studies of social capital - is associated with trust in democratic institutions (Moisés 2007, Rennó 2001). Thus, television has the potential to undermine, even if indirectly, trust that citizens place in public institutions.

Capella and Jamieson (1997) argue that the structure of political news has direct effects on public cynicism regarding politics, the government, political debates and campaigns. This happens as a result of the predominance in the media of what they call strategy coverage, which emphasizes the winning and loosing, the language of war, games and competition; the emphasis on the performance in opinion polls and candidate styles, and the great influence of opinion polls in the evaluation of candidates. This type of journalistic coverage would promote sensationalism and the simplification of complex issues, creating a 'spiral of cynicism' in the public, fomenting disengagement both from the political process and from the press.

However, this negative view about the effects of mass media on the democratic processes is not unanimous. There is a theoretical perspective 
that argues that a combination of higher educational levels and increased access to political information have helped to mobilize citizens, both in terms of behavior and increasing knowledge. It is not that the media have only positive effects. Watching television may even be associated with less knowledge and understanding of politics. Nevertheless, reading newspapers and watching television news have an inverse relationship, fostering trust in institutions and satisfaction with the functioning of democracy (Newton, 1999). News media represent a 'virtuous circle' where attention to news gradually strengthens civic engagement, while civic engagement encourages the consumption of information. Attention to news media would not only be positive for trust but also for support for democratic principles (Norris 2000).

Although both perspectives converge on the concern about the harmful effects of total television exposure, it's not possible to say that the content watched has negative effects. As television programming is plural, each message has different meanings in terms of positive or negative stimuli for democratic quality. Studies on the impact of different programming have shown how the results are not unidirectional. Variables such as interpersonal trust and civic engagement, for example, may be fostered or undermined by TV viewership depending on the type of programming (Shah 1998, Uslaner 1998).

In Brazil, there is a gap in studies on the relationship between media and public support for democracy. There is a greater interest in the effects of the media on electoral processes (Straubhaar, Olsen and Nunes 1993, Porto 1996, Miguel 1999, 2003 and 2004). There is also an interest in content analyses, which have a common and unanimous interpretation of an antipolitical bias in Brazilian media. Journalistic coverage of politics - especially of the legislative power - is frequently characterized as being negative, focusing on themes like corruption. Even if necessary in a democracy, this investigative journalism and its antipolitical stance would have the potential to disseminate distrust and aversion to politics, creating serious obstacles to the legitimacy of the democratic regime (Chaia and Azevedo 2008, Porto 2000a, Chaia and Teixeira 2001). Notwithstanding, there is also the standpoint that this antipolitical bias, although negative 
in relation to politicians as individuals, does not question the system per se, having an acquiescent character in regards to the political system and its main institutions (Miguel and Coutinho 2007).

Although these studies might suggest interesting hypotheses, we understand that the media cannot be studied solely on the basis of content analysis, since the public does not interpret messages homogeneously. Individuals are capable of critically interpreting what they consume in the media. The relevance that they have, as well as other sources of information, is given in a wider context, where other interpersonal sources - such as friends, family and organizations like the church and unions - play an equally important part (Straubhaar, Olsen and Nunes 1993).

Therefore, even if the antipolitical stance of Brazilian media is taken as a given, it is questionable that they represent an obstacle to democracy, through the depiction of corruption cases that could lead to distrust in politicians and institutions as a whole. First, we need to further analyze the content of the media itself. There is a certain consensus over the fact that the media's negative attitude is restricted to a critical appraisal of public officials. The media is not accused of being cynical of the system or of its institutions. The claim is that this negative individual characterization represents, by extension, also a negative view of the system (Porto 2000a, Chaia and Azevedo 2008). In a different perspective, it could also be argued that the emphasis on conflict and negative news coverage is a democratic function of the media, which should also act as a watchdog, holding governments accountable for their actions (Schmitt-Beck and Voltmer 2007). Far from disturbing trust in institutions, for instance, it would be the perception that the media watch power, one of the guaranties of the general climate of trust.

Contrary to what these content analyses suggest, studies based on survey statistical analysis point to more modest and positive effects of the media on perceptions of the political system. Meneguello (2010) found a modest association between information consumption in the media - especially broadcast - and critical evaluations of the functioning of democracy and institutional distrust. On the other hand, despite a period of very negative news concerning corruption scandals, viewership 
of Brazil's main Newscast, Jornal Nacional, appeared positively associated with trust and evaluation of institutions, and with satisfaction with Brazilian democracy (Mesquita 2010). Even if we consider the uncertainty about the direction of causality, these results defy the assumption that an antipolitical stance of the media can undermine confidence that citizens have in their institutions.

Differently from what part of Brazilian literature on the subject states, therefore, citizens seem to differentiate individual misconducts from failures in the working of the institutions. Publicizing irregularities and, at the same time, the institutions responsible for investigating them, confront citizens with control and accountability mechanisms present in the democratic system. The public has, thus, conditions to evaluate positively these regime instruments. News media, furthermore, are associated with other measures of democratic quality, such as political participation (Rennó 2003), and adherence to political parties as an essential element of democracy (Schlegel 2006).

Although news media seem to play a positive role in democratic quality, entertainment programming plays a more plural one, depending on their characteristics (Shah 1998). As programming is very diverse, each with different content and implications, its study presents a challenge. In Brazil, there is the perspective that fiction (especially soap operas), present politics in a negative way. The alternative of a moral solution from outside the political field, usually by some vigilante, is often presented, which could foster authoritarian movements (Porto 2000b).

In Brazil, broadcast media use is widespread, while there are both low educational levels and significant illiteracy rates. Brazilian TV and its newscasts are a privileged source of political information. Although less Brazilians use the radio, this medium still survives as a 'niche' for obtaining news. Of those who use it for this purpose, $71,5 \%$ are from Brazilian smaller countryside cities and $62 \%$ are older than 35 years old (Meneguello 2010).

Newspapers, for their part, are characterized by low readership, cumulativeness and overlapping. Of those who read newspapers at least once a week, 83\% also state they watch Jornal Nacional at least once a week, 
while the opposite is not true. Only $45 \%$ of those who state watching JN at least once a week, read newspapers the same frequency (Meneguello 2010). Despite its low circulation, the press performs an active role in denouncing corruption scandals and in setting the agenda for other media, like TV, in addition to being a 'niche' for more instructed citizens and opinion formers.

With the objective of investigating the role of the media in aspects of democratic quality, we examine here the five dimensions of political support: democratic adherence per se, support for political community, trust and evaluation of political institutions, and satisfaction with democracy. We add a sixth dimension to the analysis, which we consider also as an important part of democratic culture: the valorization of the representation function of political parties. These are the dependent variables of our study. The independent variables are: news consumption on TV (measured by viewership of Brazil's main newscast, Jornal Nacional), newspapers, radio and Internet, and total $T V$ exposure. Through statistical analyses of two national surveys ('Citizens Distrust in Democratic Institutions', 2006 and 'Latin American Public Opinion Project', 2008), the study aims to assess the impact of exposure to the media in question on Brazilians' support for their political system.

Both mobilization and media malaise theories interpret total TV exposure as having negative effects on the public. In Brazil, there is an understanding - yet to be tested empirically - that television, by presenting an anti-political bias, could restrict interpretations available for people to understand political content (Porto 2005). Thus, it is expected that in Brazil:

$\mathrm{H}_{1}$ : Watching $\mathrm{TV}$ has a negative relationship with political support variables. $^{2}$

\footnotetext{
${ }^{2}$ In the 2006 survey, it is only possible to test the variable representing the total number of hours that individuals are exposed to television. However, except for the newscast in question, it is not possible to know what other programs are being viewed. Thus, it is only possible to test the hypothesis that the total number of hours spent in front of the tv would somehow be damaging to social interactions of individuals, which, by extension, could also adversely affect variables of political support.
} 
Mobilization theories argue that exposure to news, increasing information citizens have, foster greater support for the regime and its institutions. Political support variables comprehend two general orientations. While support for the political community, adherence to democratic values and valorization of political parties are part of more axiological and normative orientations; trust and evaluation of institutions, and satisfaction with democracy, represent a more pragmatic character. Therefore:

$\mathrm{H}_{2}$ : watching news on TV and listening to news on the radio increase political knowledge and fosters both pragmatic and axiological attitudes toward democracy.

On the other hand, newspapers and the Internet reach a more elitist public in Brazil. The low circulation of newspapers in Brazil also means a larger audience segmentation, which has a higher accumulation of information obtained from other means. Thus, this 'niche' may represent the 'critical citizen' of Norris (1999). That is, the more informed citizens who are more demanding and more critical of the performance of the regime. In this sense:

$\mathrm{H}_{3}$ : Although reading newspapers and consuming news on the Internet are positively associated with axiological orientations (support for the community, adherence to democratic values and valorization of political parties), they have a negative relationship with more pragmatic dimensions (trust and evaluation of institutions, and satisfaction with democracy).

Since our independent media variables aren't all included in one single survey, we used two surveys. For total TV exposure and JN viewership, we used 'Citizens' Distrust in Democratic Institutions' (2006). ${ }^{3}$ For the rest of media variables the 'Latin American Public Opinion Project' (2008) survey was used. ${ }^{4}$ Although the language of causality is used in this text, at times, it is implicit that what we talk about is correlations, since it is not possible to attribute cause and effect relationships with this type of data.

\footnotetext{
3 Coordinated by professors Dr. José Álvaro Moisés (usp) and Dr. Rachel Meneguello (unicamp).

${ }^{4}$ Statistical treatment and interpretation of the data, however, are my own. Both surveys used national probability sample design of voting-age adults. "Citizens' Distrust Survey (2006)": 2004 interviews. Lapop survey (2008): 1,497 interviews. The sample was stratified by regions (north, northeastern, mid-west, southeastern and south) and by urban and rural areas. www.lapopsurveys.org.
} 


\section{TV and political support: television and newscast exposure}

The first results, obtained with the 2006 'Citizens Distrust in Democratic Institutions' survey show how Brazilians' main media source affects political support. Since dependent variables are ordinal, we opted for performing a categorical regression procedure. ${ }^{5}$ In all models we included socioeconomic variables as control variables. While total TV exposure was expected to have negative associations with political support, Brazil's main evening news, Jornal Nacional (hereafter referred to as JN), was expected to display associations in the opposite direction, i.e., fostering positive attitudes regarding democracy and its institutions.

In general, and as our hypothesis stated, TV viewership is negatively correlated with political support, although in a less clear cut way than expected. The dimension of democratic adherence, as well as evaluation of institutions, points to this direction as Table 1 depicts. Those who most watch TV agree more with 'governments disrespecting laws in times of trouble', that the President should 'disregard Congress and parties in times of trouble', that they 'would give a blank check to a savior leader that solved problems of the country' and that 'only a dictatorship can 'fix' Brazil'. TV viewership is also associated with a more critical appraisal of institutions (Federal Government, political parties, congressmen and senators). The dimension of satisfaction with democracy is not associated with this media variable.

However, both trust in institutions and valorization of political parties have more ambiguous results. The data presented in Table 1 reveal that, although television is associated with the idea of a single party system, it makes individuals closer to parties. As for trust in institutions, while

5 (Optimal Scalling in SPSS). Categorical Regression quantifies categorical data ascribing numerical values to categories. This results in a linear optimal linear equation for the transformed variables. All variables in the study were recoded for a positive coefficient (Beta) to always represent greater support for democracy. Therefore, for dependent variables such as "prefers democracy than savior leader", a positive Beta would represent greater agreement with the phrase. For phrases like "only a dictatorship can fix Brazil", a positive coefficient represents greater disagreement. Therefore, all positive coefficients of the study refer to a positive impact for the dimension in question. See Methodological Appendix for formulation of variables. 
this media variable is associated with less trust in the judiciary, the police and entrepreneurs, it fosters a better assessment of the Armed Forces, the Federal Government, the fire department, political parties and the President. As for the dimension of support for the political community, the relationship goes in the opposite direction as expected, fostering more pride in nationality.

These results confirm the negative association between exposure to television and various aspects of the quality of democracy (Putnam 1995, Newton 1999, Shah 1998). However, as in the 'Citizens Distrust' survey there are no variables with specific contents watched, it can only be argued that how much TV individuals watch seems to be detrimental to perceptions of democracy. As for what is watched, further studies would be needed to support or reject theories about what specific contents may represent.

Table 1: TV, Newscast and Political Support

Standardized Regression Coefficients (beta) controlled by socioeconomic variables (gender, education, age, income)

\begin{tabular}{|c|c|c|c|c|c|c|}
\hline \multicolumn{7}{|c|}{ Democratic Adherence } \\
\hline & $\begin{array}{l}\text { Disagrees w/ } \\
\text { Government } \\
\text { disrespecting } \\
\text { laws in times } \\
\text { of trouble }\end{array}$ & $\begin{array}{l}\text { Prefers } \\
\text { democra-cy } \\
\text { than savior } \\
\text { leader }\end{array}$ & $\begin{array}{l}\text { Disagrees } \\
\text { President } \\
\text { should } \\
\text { disregard } \\
\text { Congress } \\
\text { and Parties } \\
\text { in times of } \\
\text { trouble }\end{array}$ & $\begin{array}{l}\text { Disagrees } \\
\text { Country } \\
\text { better with } \\
\text { the return of } \\
\text { the military }\end{array}$ & $\begin{array}{l}\text { Disagrees } \\
\text { would give } \\
\text { a blank } \\
\text { check to } \\
\text { a savior } \\
\text { leader that } \\
\text { solved } \\
\text { problems }\end{array}$ & $\begin{array}{l}\text { Disagrees } \\
\text { only a } \\
\text { dictator- } \\
\text { ship can fix } \\
\text { Brazil }\end{array}$ \\
\hline TV & $-0,051^{* * * * *}$ & $0,059^{\text {****** }}$ & $-0,086^{* * * *}$ & $\mathrm{~ns}$ & $-0,058^{\text {***:**k }}$ & $-0,077^{\text {**:k*k }}$ \\
\hline TXJN & Ns & ns & \multirow{2}{*}{\multicolumn{2}{|c|}{$\begin{array}{l}\text { Ns } \\
0,021\end{array}$}} & ns & $-0,062^{* * *}$ \\
\hline $\mathrm{R}^{2}$ & 0,018 & 0,013 & & & 0,03 & 0,035 \\
\hline \multicolumn{7}{|c|}{ Political Community } \\
\hline \multicolumn{7}{|c|}{ Proud to be Brazilian } \\
\hline TV & \multicolumn{6}{|l|}{$0,069^{* * * *}$} \\
\hline TXJN & \multicolumn{6}{|l|}{$0,046^{*}$} \\
\hline $\mathrm{R}^{2}$ & \multicolumn{6}{|l|}{0,014} \\
\hline \multicolumn{7}{|c|}{ Valorization of political parties } \\
\hline & \multicolumn{2}{|c|}{$\begin{array}{l}\text { Democracy has to do with } \\
\text { the existence of various } \\
\text { political parties }\end{array}$} & \multicolumn{3}{|c|}{$\begin{array}{l}\text { Disagrees Brazil would be better } \\
\text { if there were only one political } \\
\text { party }\end{array}$} & $\begin{array}{l}\text { Closeness to } \\
\text { political party }\end{array}$ \\
\hline TV & \multicolumn{2}{|c|}{ Ns } & \multicolumn{2}{|l|}{ 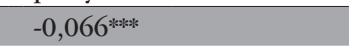 } & \multicolumn{2}{|c|}{$0,088^{\text {keklek }}$} \\
\hline TXJN & \multicolumn{2}{|l|}{ Ns } & \multicolumn{2}{|l|}{ ns } & \multicolumn{2}{|c|}{$0,098^{* * 2 * k}$} \\
\hline $\mathrm{R}^{2}$ & & \multicolumn{3}{|c|}{0,023} & \multicolumn{2}{|c|}{0,027} \\
\hline
\end{tabular}


Trust in Institutions

\begin{tabular}{|c|c|c|c|c|c|}
\hline & Judiciary & Armed Forces & Congress & $\begin{array}{l}\text { Federal } \\
\text { Government }\end{array}$ & $\begin{array}{l}\text { Fire } \\
\text { department }\end{array}$ \\
\hline TV & $-0,048^{* * k}$ & $0,092 * * * *$ & $0,039^{*}$ & $0,056^{* * * * \cdots}$ & $0,084^{* * * * *}$ \\
\hline TXJN & Ns & $0,111^{* * * *}$ & ns & $0,062 * *$ & $0,079^{* * * *}$ \\
\hline \multirow[t]{2}{*}{$\mathrm{R}^{2}$} & 0,022 & 0,035 & 0,028 & 0,03 & 0,035 \\
\hline & Police & Political parties & President & Unions & Entrepreneurs \\
\hline TV & $-0,060^{* * * * *}$ & $0,046^{* *}$ & $0,081^{\text {***:** }}$ & ns & $-0,044^{*}$ \\
\hline TXJN & Ns & Ns & $0,053^{\text {*** }}$ & ns & ns \\
\hline $\mathrm{R}^{2}$ & 0,024 & 0,021 & 0,058 & & 0,024 \\
\hline \multicolumn{6}{|c|}{ Evaluation of Institutions } \\
\hline & \multicolumn{2}{|c|}{$\begin{array}{l}\text { Congressmen and } \\
\text { Senators }\end{array}$} & gress & \multicolumn{2}{|c|}{ Federal Government } \\
\hline TV & \multicolumn{2}{|l|}{$-0,048^{* * * * *}$} & Ns & \multicolumn{2}{|l|}{$-0,039 * *$} \\
\hline TXJN & \multicolumn{3}{|l|}{ Ns } & \multicolumn{2}{|l|}{ ns } \\
\hline $\mathrm{R}^{2}$ & \multicolumn{3}{|l|}{0,023} & \multicolumn{2}{|l|}{0,043} \\
\hline & \multicolumn{2}{|c|}{ President Lula } & Political parties & \multicolumn{2}{|c|}{ President } \\
\hline TV & \multicolumn{2}{|l|}{$0,05^{* * * * *}$} & $-0,06^{* * k * k}$ & \multicolumn{2}{|l|}{ ns } \\
\hline TXJN & \multicolumn{2}{|l|}{ Ns } & Ns & \multicolumn{2}{|l|}{ ns } \\
\hline $\mathrm{R}^{2}$ & 0,05 & \multicolumn{2}{|c|}{0,022} & & \\
\hline & & Satisfaction & with Demc & & \\
\hline tv & ns & & & & \\
\hline $\operatorname{txjn}$ & $0,049^{*}$ & & & & \\
\hline $\mathrm{R}^{2}$ & 0,04 & & & & \\
\hline
\end{tabular}

Significance: *p $<0,10, * * \mathrm{p}<0,05, * * *<0,01$. Source: "Citizens' Distrust in Democratic Institutions" (2006).

In the opposite direction of TV viewership, it was expected that Brazil's main newscast fostered political support. Those who watch JN are also exposed to several other political messages on television. For instance, it seems reasonable to suppose that there is a difference between individuals who watch JN three times a week - while watching only one hour of TV a day - and another person who watches the same amount of JN, but at the same time has a four hour daily consumption of television. Thus, we used a JN viewership rate, which corresponds to the proportion of consumption of the newscast in relation to the total hours devoted to television, created by a division between JN viewership by TV viewership. 
The idea here is not only a possible 'dilution' of information compared to one that is more 'pure'. It is expected that a viewer who practically restricts his TV consumption to the newscast is more attentive to its content, since he turns his TV set on with the express purpose of knowing the news of the day. However, a distinct pattern of viewership, in which the individual leaves his TV on from the period that he arrives from work until he goes to sleep - watching JN 'between the soap operas' - may indicate a less attentive pattern. This variable created proved to be a more consistent one compared to just JN viewership in a previous study (Mesquita 2010). When we speak of JN audience from now on, we are referring to this rate, i.e., always taking into account television exposure.

Where there were significant correlations, the tested models supported our hypothesis. Watching JN fosters pride in nationality, trust in institutions, valorization of political parties and satisfaction with democracy. It is not a relevant variable for evaluation of institutions or democratic adherence, with exception of one negative association with rejection of dictatorship (see Table 1 ).

\section{Secondary news sources and political support: newspapers, radio and the Internet}

The next set of results concerns the role that news consumption on the radio, newspapers and the Internet represent for the same dimensions presented in the former analyses. The database used was the 2008 Lapop survey. Listening to news on the radio, as expected, proved to foster political support. Although it is not a relevant variable for democratic adherence or satisfaction with democracy, it fosters greater pride in nationality, valorization of political parties, trust and positive assessments of institutions, as presented in Table 2 .

Consumption of newspapers and of news on the Internet - since corresponding to a more elitist and well-informed public - was expected to foster axiological attitudes toward democracy, while increasing a more critical assessment of pragmatic dimensions of the regime. This was sustained in part. Reading newspapers does foster both valorization of political parties and a more critical assessment of institutions (trust, evaluation and satisfaction 
with the functioning of the regime). However, democratic adherence per se presents an ambiguous correlation. The press fosters more disapproval of censure, but at the same time undermines the idea of democracy as the best form of government. It is also related to less pride in nationality.

Table 2: Newspaper, Radio, Internet and Political Support Standardized Regression Coefficients (beta) controlled by socioeconomic variables (gender, education, age, income)

Democratic Adherence

\begin{tabular}{lll}
\hline & $\begin{array}{l}\text { Democracy has some problems, } \\
\text { but is better than any other form } \\
\text { of government }\end{array}$ & $\begin{array}{l}\text { Disapproves that Government } \\
\text { censures television programs }\end{array}$ \\
\hline Newspapers & $-0,076^{* * * * *}$ & $0,071^{* * * *}$ \\
Radio & $\mathrm{ns}$ & $\mathrm{ns}$ \\
Internet & $0,104^{* * * *}$ & $\mathrm{~ns}$ \\
$\mathrm{R}^{2}$ & 0,037 & 0,035 \\
\hline
\end{tabular}

Political community

\begin{tabular}{ll}
\hline & Proud to be Brazilian \\
\hline Newspapers & $-0,113^{* * * *}$ \\
Radio & $0,108^{* * * *}$ \\
Internet & $-0,052^{*}$ \\
$\mathrm{R}^{2}$ & 0,038 \\
\hline
\end{tabular}

Valorization of Political Parties

\begin{tabular}{|c|c|c|c|c|}
\hline & $\begin{array}{l}\text { Disagrees there } \\
\text { can be democracy } \\
\text { without parties }\end{array}$ & $\begin{array}{l}\text { Political parties represent } \\
\text { well their electors }\end{array}$ & $\begin{array}{l}\text { Parties are } \\
\text { close to people } \\
\text { like me }\end{array}$ & $\begin{array}{l}\text { Corruption } \\
\text { perception } \\
\text { in parties }\end{array}$ \\
\hline Newspapers & ns & ns & $0,084^{* * * \cdots *}$ & $0,078^{\text {*k:kek }}$ \\
\hline Radio & ns & ns & $0,085^{* * * * *}$ & ns \\
\hline Internet & ns & ns & ns & ns \\
\hline $\mathrm{R}^{2}$ & & & 0,039 & 0,02 \\
\hline
\end{tabular}

Trust in Institutions

\begin{tabular}{|c|c|c|c|c|c|c|}
\hline & Entrepreneurs & Judiciary & $\begin{array}{l}\text { Armed } \\
\text { Forces }\end{array}$ & Congress & $\begin{array}{l}\text { Federal } \\
\text { Government }\end{array}$ & Unions \\
\hline Newspapers & $-0,056^{*}$ & $-0,089^{\text {**⿲:丨 }}$ & $-0,066^{\text {***: }}$ & $-0,110^{\text {****** }}$ & $-0,139^{* * * * *}$ & ns \\
\hline Radio & $0,046^{\text {*** }}$ & $0,071^{* * * *}$ & 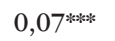 & ns & $0,05^{\text {*** }}$ & $0,087^{\text {*k*k }}$ \\
\hline Internet & $0,073^{\text {****** }}$ & 0,059 *** & ns & ns & ns & $-0,114 * * * *$ \\
\hline \multirow[t]{2}{*}{$\mathrm{R}^{2}$} & 0,025 & 0,055 & 0,038 & 0,036 & 0,056 & 0,039 \\
\hline & Military Police & $\begin{array}{l}\text { Federal } \\
\text { Police }\end{array}$ & $\begin{array}{l}\text { Political } \\
\text { parties }\end{array}$ & President & $\begin{array}{l}\text { Supreme } \\
\text { Court }\end{array}$ & $\begin{array}{l}\text { Fire } \\
\text { department }\end{array}$ \\
\hline Newspapers & $-0,107^{\text {****** }}$ & $-0,114^{\text {**⿲:丶k }}$ & $-0,06 * *$ & $-0,106^{\text {******* }}$ & $-0,115^{\text {****** }}$ & ns \\
\hline Radio & $0,133^{\text {****** }}$ & $0,114^{* * * *}$ & $0,046^{*}$ & $0,051^{*}$ & $0,076^{\text {*k:k*k }}$ & ns \\
\hline Internet & ns & ns & ns & ns & ns & $-0,062^{*}$ \\
\hline $\mathrm{R}^{2}$ & 0,068 & 0,04 & 0,031 & 0,059 & 0,029 & 0,015 \\
\hline
\end{tabular}


Satisfaction with Democracy

\begin{tabular}{|c|c|c|c|}
\hline Newspapers & \multicolumn{3}{|l|}{$-0,108^{* * * * *}$} \\
\hline Radio & \multicolumn{3}{|l|}{ ns } \\
\hline Internet & \multicolumn{3}{|l|}{ ns } \\
\hline $\mathrm{R}^{2}$ & \multicolumn{3}{|l|}{0,042} \\
\hline \multicolumn{4}{|c|}{ Evaluation of Institutions } \\
\hline & $\begin{array}{l}\text { Government promotes } \\
\text { democratic principles }\end{array}$ & $\begin{array}{l}\text { Government fights } \\
\text { corruption }\end{array}$ & $\begin{array}{l}\text { Congress makes } \\
\text { important laws }\end{array}$ \\
\hline Newspapers & $-0,099^{\text {*k:k*k }}$ & $-0,103^{* * * * *}$ & $-0,059^{* * * *}$ \\
\hline Radio & $0,09^{* * * * *}$ & $0,097^{* * * *}$ & $0,052^{*}$ \\
\hline Internet & $-0,068^{\text {skek:k }}$ & ns & ns \\
\hline \multirow[t]{2}{*}{$\mathrm{R}^{2}$} & 0,047 & 0,041 & 0,024 \\
\hline & Congress acts as expected & President Lula & Congressmen \\
\hline Newspapers & ns & 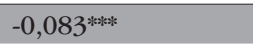 & $0,088^{\text {***:**: }}$ \\
\hline Radio & $0,057^{* *}$ & ns & $0,103^{* * * * *}$ \\
\hline Internet & $-0,056^{*}$ & ns & ns \\
\hline $\mathrm{R}^{2}$ & 0,021 & 0,023 & 0,032 \\
\hline
\end{tabular}

Significance: ${ }^{*} \mathrm{p}<0,10, * * \mathrm{p}<0,05, * * * 0,01$. Source: Lapop (2008).

Consumption of news on the Internet is correlated with more democratic adherence. However, the correlation with pride in nationality goes in the opposite direction, while it is not a significant variable for the dimension of valorization of political parties or satisfaction with democracy. The Internet is associated with a more critical assessment of institutions in terms of evaluation. In terms of trust, however, it depends on the institution in question. The more news consumption on the web, the more individuals trust entrepreneurs and the judiciary, and the less they trust unions and the Fire Department. Trust in most institutions, however, is not affected by this media variable.

\section{Brief Final Considerations}

The media are a relevant factor to be considered for the understanding of public affairs. The information they contain might help to engage citizens in democracy, or estrange them from democratic principles. To understand the role of the media in public support for democracy, we need to consider different impacts of various sources that citizens are exposed to. 
The results presented here confirm this plural role played by the media, depending not only on the medium in question, but also on the dimensions of political support analyzed. On the one hand, even though news media in Brazil seems to be somewhat positive for political support, as the case of other countries, the picture seems a little more complex for the former. Brazil's main news source, Jornal Nacional, and attention to news on the radio, seem to foment a better view of democratic institutions. Although presenting politics from a critical perspective - denouncing corruption scandals - they perform a positive role presenting democratic institutions and mechanisms as a way to deal with them, which could be responsible for the positive correlation found.

On the other hand, probably because reaching a more segmented elitist public, newspaper consumption and attention to news on the Internet have a more complex picture. As predicted, these media sources are correlated with a more critical assessment of the functioning of democratic institutions. As for more axiological attitudes of political support, it is not totally positive as expected. While, for the most part, they seem to foster democratic attitudes (less so for newspapers) and valorize political parties, both media are negatively correlated with support for the political community.

The case of television also seems to be particular to the Brazilian case. In general - and as predicted - viewership is negatively associated with variables of democratic adherence and evaluation of institutions and political actors. Although more ambiguously (depending on the variable in question), it is also negatively correlated with valorization of political parties and trust in institutions. However, despite this negative role, the data also showed that television promotes greater adherence to the political community.

These results demonstrate that it is not accurate to blame an anti-political bias of the media for negative attitudes that citizens have regarding democracy. Even if a more critical attitude toward politics by news media is taken as a given, there is controversy about this representing, by extension, an anti-institutional attitude. Here, as in the case of other countries (Norris 2000, Newton 1999), news has appeared constantly as a positive factor for democratic quality. 
As for television viewership, the results somehow confirm concerns about its meaning to perceptions of democracy in Brazil. Still, these results require caution, as they seem to be more associated with time spent watching television than with what is being watched. To test possible negative effects of content, more survey studies were needed with more detailed questions about specific programming. Reception studies could also be useful in this regard. In addition, we emphasize that television presents itself as a positive factor for adherence to the political community.

This result for pride in nationality could be related to the great dissemination of TV countrywide, with diffusion of common values. Taking the example of the genre of soap operas, all social classes watch this type of programming, talking about their themes and plots, which makes television act as a social bond. Representing a mirror of Brazilian society, the soaps also present themselves as a structuring factor of Brazilian identity (Wolton 1996). Thus, television can be seen as paradoxical. Although - as in other countries- it seems to be somehow tied to more negative attitudes toward politics, at the same time, in Brazil, it plays an active role - allowing the audience to build complex understandings about the past, the present and future of the country.

The argument set forward here makes the role of the media in political support a complex one. Firstly, not all media are alike. Some foster more positive political attitudes, while others seem to support the 'political disaffection' theory. Secondly, even among specific media, the roles they play are not clear-cut. They might promote some dimensions of political support, while undermining others.

Another consideration should be made regarding directionality of associations. As said before, from this type of data, it is not possible to say whether media impact political attitudes, or if citizens with certain political opinions turn to the type of media that display the worldview they already have. In this sense, it seems that different media in question might offer diverse suggestions for this relationship.

Television newscasts, as Jornal Nacional for example, have a more diversified audience. Many people watch it because they have their TV sets on between their favorite entertainment shows. In this case, it could be 
suggested of an actual positive role of the newscast, which has the potential to reach an audience previously not interested in public affairs. Conversely, the secondary sources of news analyzed here could suggest a different causal relationship. Since they are more selective in terms of consumers, it does seem plausible that they are read, listened to or watched by a public that has the same points of view these media convey. Nevertheless, a better way to understand these effects could be as a two-way flow. Although people turn to these media because they reflect certain points of view they already have, they reinforce these previous attitudes, which could be of support of democratic values, or estrangement from politics in general.

\section{References}

Almond, G. and Verba, S. (1963) The civic culture: Political attitudes in five western democracies. Princeton: Princeton University Press.

Cappella, J. and Jamieson, K. (1997) Spiral of cynicism. The press and the public good. New York/Oxford: Oxford University Press.

Chaia, V. and Teixeira, M. (2001) 'Democracia e escândalos politicos'. São Paulo em Perspectiva, 15(4).

Chaia, V. and Azevedo, F. (2008) 'O senado nos editoriais paulistas (2003-2004)'. Opinião Pública, 14(1).

Coleman, J. (1990) Foundations of social theory. Cambridge, MA: Harvard University Press.

'Desconfiança dos cidadãos das instituições democráticas, A', (2006) Survey of the project coordinated by professors Moisés, J. (usp) and Meneguello, R. (Unicamp), Fapesp (process: 04/07952-8).

Dalton, R. (1999) 'Political support in advanced industrial democracies' in P. Norris (ed.) Critical citizens: Global support for democratic governance. Oxford: Oxford University Press.

Diamond, L. and Morlino, L. (2004) 'The quality of democracy - an overview',Journal of Democracy, 15(4).

Easton, D. (1965) A system analysis of political life. New Cork: Wiley.

Inglehart, R. (2002) 'Cultura e democracia' in L. Harrison and S. Huntington, A cultura importa - Os valores que definem o progresso humano. Rio de Janeiro e São Paulo: Ed. Record.

Inglehart, R. and Welzel, C. (2005) Modernization, cultural change and democracy. New York: Cambridge University Press.

'Latin American Public Opinion Project' (2008) www.lapopsurveys.org.

Meneguello, R. (2010) 'Aspectos do desempenho democrático: Estudo sobre a adesão à democracia e avaliação do regime' in J. Moisés (ed.) Democracia e confiança: Por que os cidadãos desconfiam das instituições públicas?. São Paulo: Edusp.

Mesquita, N. (2010) 'Jornal Nacional, democracia e confiança nas instituições democráticas' in J. Moisés, (ed.) Democracia e confiança: Por que os cidadãos desconfiam das instituições públicas. São Paulo: Edusp. 
Miguel, L. (1999) 'Mídia e eleições: a campanha de 1998 na Rede Globo'. Dados, 42(2).

Miguel, L. (2003) 'A eleição visível: A Rede Globo descobre a política em 2002'. Dados, 46(2).

Miguel, L. (2004) 'Discursos cruzados: Telenoticiários, HPEG e a construção da agenda eleitoral',Sociologias, 6(11).

Miguel, L and Coutinho, P. (2007) 'A crise e suas fronteiras: Oito meses de mensalão nos editoriais dos jornais'. Opinião Pública, 13(1).

Moisés, J.(2007)'Democracy, political trust and democratic institutions (the case of Brazil)'. Paper presented in the seminar Democracy and citizens distrust of public institutions in Brazil in comparative perspectives, Oxford University, 1.\%/jun./2007.

Moisés, J. (2008) 'Os Significados da democracia segundo os Brasileiros' in IV Congresso da Associação Latino-americana de Ciência Política - ALACIP, Gobernanza sin Desarrollo? Repensar el Bienestar en America Latina, Costa Rica.

Moisés, J. (2010) 'Cultura política, instituições e democracia: Lições da experiência brasileira' in J. Moisés, Democracia e confiança: Por que os cidadãos desconfiam das instituições públicas? São Paulo: Edusp.

Moisés, J. and Carneiro, G. (2010) 'Democracia, desconfiança política e insatisfação com o regime - o caso do Brasil' in J. Moisés (ed.) Democracia e confiança: Por que os cidadãos desconfiam das instituições públicas?. São Paulo: Edusp.

Newton, K. (1999) 'Mass media effects: Mobilization or media malaise?' in British Journal of Political Science, 29(4).

Norris, P. (ed) (1999) Critical citizens, Oxford: Oxford University Press. Norris, P.(2000)A virtuous circle: Political communications in post-industrial democracies. Cambridge: Cambridge University Press.

North, D. (1990) Institutions, institutional change and economic performance. Cambridge, UK: Cambridge University Press.

Patterson, T. (1998) 'Time and news: the media's limitations as an instrument of democracy',in International Political Science Review, 19(1).

Patterson, T. (2000) 'The United States: news in a free-market society' in R. Gunther and A. Mughan (eds.) Democracy and the media: A comparative perspective. Cambridge: Cambridge University Press.

Putnam, R. (1995) 'Tuning in, tuning out: The strange disappearance of social capital in America' in PS - Political Science and Politics, XXVIII (4).

Porto, M. (1996) 'Televisão e voto: A eleição de 1992 para prefeito de São Paulo' in Opinião Pública, IV(1).

Porto, M. (2000a) 'La crisis de confianza en la política y sus instituciones: Los medios y la legitimidad de la democracia en Brasil' in América Latina Hoy, 25.

Porto, M. (2000b) 'Telenovelas, política e identidad nacional en Brasil' in Ecuador Debate, 49.

Porto, M. (2005) 'The principle of diversity in journalism: Jornal Nacional and political deliberation in Brazil' in Brazilian Journalism and Research, 1(1).

Rennó, L. (2001) 'Confiança interpessoal e comportamento político: Microfundamentos da teoria do capital social na América Latina' in Opinião Pública, VII(1).

Rennó, L. (2003) 'Estruturas de oportunidade política e engajamento em organizações da sociedade civil: Um estudo comparado sobre a América Latina' in Revista de Sociologia e Política, 21.

Schlegel, R. (2006) 'Mídia, confiança política e mobilização', Masters dissertation, fflch-usp, São Paulo. 
Schmitt-Beck, R. and Voltmer, K. (2007) 'The mass media in third-wave democracies: Gravediggers $\leq$ Democracy, intermediation, and voting on four continents. Oxford: Oxford University Press.

Shah, D. (1998) 'Civic engagement, interpersonal trust and television use: An individual-level assessment of social capital' in Political Psychology, 19.

Straubhaar, J., Olsen, O. and Nunes, A. (1993) 'The Brazilian case' in T. Skidmore (ed.) Television, politics, and the transition to democracy in Latin America. Washington: WWC Press; Baltimore/London: JHU Press.

Uslaner, E. (1998) 'Social capital, television, and the 'mean world: Trust, optimism, and civic participation' in Political Psychology, 19.

Wolton, D. (1996) Elogio do grande public, São Paulo: Ática.

\section{Methodological Appendix}

Lapop (2008) Survey:

Independent variables:

\section{Newspaper readership}

"How often do you read newspapers (everyday, once or twice a week, rarely, never)."

\section{News on the radio}

"How often do you listen to news on the radio (everyday, once or twice a week, rarely, never)."

\section{News on the Internet}

"How often do you read or listen to news on the Internet (everyday, once or twice a week, rarely, never)."

Dependent variables:

\section{Adherence to Democracy and Democratic Values:}

"Democracy has some problems, but is better than any other form of government (Disagree a lot, 2, 3, 4, 5, 6, agree a lot)".

"With which of the following phrases do you agree more? (Democracy is preferable to any other form of government; in some circumstances 
an authoritarian regime may be preferable; it makes no difference if a regime is authoritarian or democratic").

"In order to arrest criminals, do you believe the authorities must always respect laws or that, in certain occasions, authorities can act without respecting laws (Must always respect laws, in certain occasions can act without respect to laws)."

"To what point do you approve or disapprove that the government censures TV programming (Totally disapprove, 2, 3, 4, 5, 6, 7, 8, 9, totally approve)"

\section{Adberence to Political Community}

"How proud are you of being Brazilian? (Not proud at all, 2, 3, 4, 5, 6 , very proud)"

\section{Adberence to political parties}

"Thinking about political parties in general, how much do you agree or disagree that Brazilian political parties represent their electors well? (Disagree a lot, 2, 3, 4, 5, 6, agree a lot)"

"How much corruption is there in Brazilian political parties? (None, $2,3,4,5,6$, a lot)"

"How close are political parties to people like me? (Not close at all, 2, 3, 4, 5, 6, very close)."

"There can be democracy without political parties (Disagree a lot, 2, 3, 4, 5, 6, agree a lot).”

"How much trust do you have in political parties (None, 2, 3, 4, 5, 6, a lot)."

\section{Evaluation of Institutions}

"Up to what point would you say (not at all, 2, 3, 4, 5, 6, a lot): 'Congress passes laws and policies important to the country'; 'Congress 
corresponds to what is expected from it'; 'The Federal Government fights corruption'; 'The Federal Government promotes and protects democratic principles'."

"And speaking in general about the current Government, how do you evaluate the work President Lula has been doing?" (Very bad, bad, neither good nor bad, good, very good)

"Do you think congressmen are doing a (Very bad, bad, neither good nor bad, good or very good) work?"

\section{Satisfaction with Democracy}

"Generally speaking, are you very satisfied, satisfied, dissatisfied, very dissatisfied with the functioning of democracy in Brazil?"

\section{Institutional Trust}

"Up to what point do you trust (not at all, 2, 3, 4, 5, 6, a lot): entrepreneurs, the judiciary, the armed forces, Congress, Federal Government, unions, military police, federal police, political parties, The President, supreme court, fire department"

\section{“Citizens' Distrust in Democratic Institutions" (2006) Survey: \\ Independent variables:}

\section{TV viewership}

"How many hours a day do you spend watching TV (up to 1, 2, 3, 4, 5 hours, more than 5 hours? Or you do not usually watch TV?)"

Jornal Nacional viewership

"How often do you watch TV Globo's Jornal Nacional during the week? (1, 2, 3, 4, 5 times, every day or you never watch JN?) "

\section{Dependent variables:}

\section{Adberence to Democracy and Democratic Values:}

Would you say you (strongly disagree, somewhat disagree, somewhat agree, strongly agree): 
"When there is a difficult situation in Brazil, it doesn't matter if the Government disregards laws, the Congress and institutions to solve the problems of the country."

"I Prefer Democracy rather than a savior leader who has all power, without being controlled by laws"

"If the country is facing serious difficulties, the President may disregard parties and Congress and make decisions alone"

"The country would be better off if the military returned to power"

"I'd give a blank check to a savior leader to solve the problems of the country"

"Only a dictatorship can fix Brazil"

\section{Adberence to Political Community}

"Are you proud of being Brazilian? (Not proud at all, a little proud, proud, very proud)"

\section{Adberence to political parties}

"Speaking of the Brazilian political parties, how do you feel about them?" (Very close, close, somewhat close, not close to any "

"Brazil would be better off if there were only one political party"

"Speaking of democracy, do you think democracy has to do with: the existence of several political parties" (has much to do, has to do, has little to do, has nothing to do)

\section{Evaluation of Institutions}

I would like you to say what is your evaluation - very good, good, neither good nor bad, bad or very bad - of each one of the following institutions: a) the army; b) the judiciary power; c) police; d) the 
National Congress; e) the political parties; f) the Government; g) the President.

\section{Satisfaction with Democracy}

"Would you say that you are very satisfied, satisfied, not very satisfied, or not at all satisfied with the functioning of democracy in Brazil?"

\section{Institutional Trust}

"I am going to mention now some public institutions and would like to know what is the degree of trust that you have for each one of them: a lot, some, a little or not trust at all: a) the army, b) the firemen, c) judiciary power, d) president, e) police, f) government, g) National Congress, h) political parties and

"I am going to mention now some private institutions and would like to know what is the degree of trust that you have in each one of them: a lot, some, a little or not trust at all": the unions, the entrepreneurs" 